\title{
PUBLIC EXPENDITURE
}




\section{ALDINE TREATISES IN MODERN ECONOMICS}

edited by Harry G. Johnson

University of Chicago and

London School of Economics 


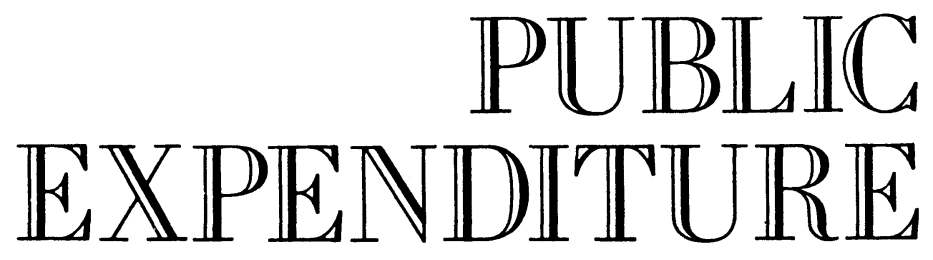

Jesse Burkhead | Jerry Miner

Syracuse University

Palgrave Macmillan 


\section{ABOUT THE AUTHORS}

JESSE BURKHEAD is Maxwell Professor of Economics at Syracuse University. Educated at the University of Wisconsin and Harvard University, he has taught at Lehigh University as well as at Syracuse. Professor Burkhead has served on numerous professional and advisory boards. His books include Government Budgeting, State and Local Taxes for Public Education, and Public School Finance - Economics and Politics. He is coauthor of River Basin Administration and the Delaware, Decisions in Syracuse, and Inputs and Outputs in Large City Education.

JERRY MINER, Professor of Economics at Syracuse University, received his Ph.D. in Economics from the University of Michigan. He has been Senior Research Economist for UNESCO in Paris, and an Assistant Study Director of the Survey Research Center at the University of Michigan. The author of Social and Economic Factors in Spending for Public Education, Professor Miner has contributed widely to the literature of economics.

ISBN 978-1-349-01374-6 ISBN 978-1-349-01372-2 (eBook)

DOI 10.1007/978-1-349-01372-2

Copyright $(9)$ r 97 I by Jesse Burkhead and Jerry Miner

Softcover reprint of the hardcover 1st edition 1971 978-0-333-13266-1

All rights reserved. No part of this publication may be reproduced or transmitted, in any form or by any means, without permission.

First published 197 I by Aldine - Atherton, Inc.

First published in Great Britain 197 I

Published by

THE MACMILLAN PRESS LTD

London and Basingstoke

Associated companies in New York Toronto

Dublin Melbourne Johannesburg and Madras

SBN $333 \quad$ I $3266 \quad$ I 


\section{Foreword}

The purpose of the Aldine Treatises in Modern Economics is to enable authorities in a particular field of economics, and experts on a particular problem, to make their knowledge available to others in the form they find easiest and most convenient. Our intention is to free them from an insistence on complete coverage of a conventionally defined subject, which deters many leading economists from writing a book instead of a series of articles or induces them to suppress originality for the sake of orthodoxy, and from an obligation to produce a standard number of pages, which encourages the submergence of judgment of relevance in a pudding of irrelevant detail. The Aldine Treatises seek to encourage good economists to say what they want to say to their fellow economists, in as little or as much space as they consider necessary to the purpose.

The present volume treats of the economics of public expenditure. This is a relatively new and rapidly growing field of economic analysis and policy. Economics in the past has tended to concentrate on the economics of taxation, on the assumption that the scope of the objects of public expenditure is given by nature or society and the main problem is to allocate the tax burden equitably and with minimum loss of economic efficiency. It is only recently that economists have come to enquire into the reasons why certain kinds of expenditure are assigned to the public sector (the theory of public goods), the logic of the assignment and of the processes by which the total amount of public expenditure and its allocation among alternatives are determined, the criteria for efficiency in the spending of public money, the implications of the division of responsibility for expenditures among different levels of government, and the actual behavior of governmental units viewed simply as economic units attempting to maximize their objectives subject to a budget constraint. 
The analysis of the public sector, more so probably than other economic units such as the firm or household, lends itself to many different approaches, from that of the pure economic theorist interested in public goods, externalities, and market failures to that of the cost-benefit analyst interested in assessing alternative public investment opportunities and in relating expenditure programs to social objectives, and from that of the theorist interested in the philosophical problems of social choice to that of the coldly applied economist seeking to find empirical regularities in the behavior of governmental units. One can concentrate on the purely theoretical issues, or on the operational problems of decision-making with respect to public expenditure, or on empirical observation of governmental behavior.

One unfortunate consequence of this variety of possible approaches, for the student of the subject, is that the relevant literature is widely scattered as regards place of publication, and that the techniques employed for different aspects of the problem are extremely heterogeneous. To keep up with the field, the student and his teacher must read omnivorously, and be extremely versatile in their capacity to use the various tools of economic analysis. For the economist actually engaged in the formulation of public policy, the task might well seem hopeless.

The authors of the present Treatise realized the need for a monograph that would bring together, survey, and synthesize the main developments in the analysis and treatment of the public sector, and decided to pool their talents in order to make the survey as authoritative as possible over the extremely wide range of topics that rightfully demanded inclusion. Each has made independent contributions to the development of the field, and can write authoritatively about it. The result of their collaboration is a happy blend of individual expertise raised to a higher power, in which the reader is furnished with a carefully evaluated summary of the major contributions of a great variety of authors, set within a broader context of concern about the major issues revealed by past scholarship, and illuminated by a conscientious awareness of those issues that remain unresolved. Readers at all levels should find this Treatise a useful guide to the nature and merits of the work done so far in this rapidly-developing field, as well as to the problems and issues that remain open.

HARRY G. JOHNSON 


\section{Preface}

In the years since World War II economists generally and public finance economists in particular have become increasingly involved in both the theory and policy analysis of public expenditures. No doubt the growth of the public sector, in both developed and underdeveloped nations, has contributed to this involvement. And no doubt the increased importance of military expenditures in the budgets of many nations, with a resultant pressure on public resources for nonmilitary purposes, has also contributed to a heightened concern over the composition and level of public outlay.

The traditional analytic framework of economics has not been wholly adequate for the tasks that have been confronted. Theory and policy analysis in economic stabilization are reasonably well developed; we have not attempted here either to synthesize or to add to this body of knowledge. But other areas are less secure. The nature of preferences and their relationship to individual and group welfare is not yet satisfactorily resolved.

The concern for attaining efficiency has continued to be significant, but in recent years has been joined by a concern with the distributional aspects of public expenditures. A successful conceptualization of the ideal merger of efficiency and distributional objectives in the public sector has not yet been attained. The "new" welfare economics has been no more successful in specifying an optimum for the public sector, and its integration with the private sector, than in specifying an optimum for purely market-type conditions. As a result, the field of public expenditure is in a somewhat unsettled state in both theory and practice, and the authors of this volume find themselves writing into and about a number of areas where neither doctrine nor practice has yet been resolved.

In consequence, we feel that we owe to our readers a statement of the 
presuppositions on which this volume rests. These are first, that fiscal theory has significance only in an operational context - in the analysis of policy alternatives, in the choice among fiscal instruments to achieve societal goals, and in particular in the context of budget procedures and budget systems. Thus we move from an examination of the pure theory of public goods to an examination of the political context of budget making and to the development of program budgeting and its principal analytic tool, benefit-cost analysis. We also stress that the theory and practice of multilevel finance is relevant to the analysis of public expenditures, both to their objectives and to their outcomes.

A second presupposition on which this volume rests is that every effort must be made, in the analysis of expenditure policy, to embrace distributional objectives. We are convinced that the failure to combine distributional considerations with efficiency considerations is a major continuing deficiency in fiscal theory, and we are also convinced that distributional considerations are, at minimum, capable of being handled systematically, even if not definitively, within the theory and practice of public expenditures.

In addition, this volume is characterized by a continued concern for the nature of preferences, their aggregation, and their expression in a political context. The study of public expenditure is, of course, a study in the politics of economics. This must be approached both through an examination of the "purely" economic considerations that are relevant and with recognition that noneconomic considerations also are significant.

Our acknowledgments of indebtedness are substantial. Many graduate students in economics have been subjected to these materials, in one form or another, and we have profited greatly from their critical comments. Our colleagues in the Department of Economics, Syracuse University, have been most generous in their efforts to improve these chapters. In particular, we are indebted to Melvin A. Eggers, John Henning, Katharine Lyall, Seymour Sacks, Edward J. Stevens, Sidney Sufrin, and A. Dale Tussing. Our colleagues in Political Science, Alan K. Campbell, Julian Friedman, and Dwight Waldo, have also been most helpful, as has Harry P. Hatry of the Urban Institute. One of the authors (Burkhead) is indebted to the Brookings Institution for its hospitality and intellectual stimulus in the fall of 1966 when these chapters were in their first stage. Harry G. Johnson, the editor of this series, has been unsparingly critical of earlier drafts of these chapters; his comments have been of great value.

Finally, we would acknowledge the patience and skill of Virginia Halsey who typed the numerous revisions of these chapters, and the assistance of Steven and Philip Miner in the preparation of the index. Also, we express our appreciation to Christine Valentine of Aldine - Atherton, who contributed so much to the transition from manuscript to book. 


\section{Contents}

Foreword $\quad$ v

Preface vii

1. The Nature of the Public Sector 1

The Growth of Government - Public Sector Goals - Organizational Characteristics - The Government Budget - Behavioral Characteristics - Economic Analysis

2. The Pure Theory of Public Expenditure: Partial Equilibrium

The Concept of Public Goods - Partial Equilibrium Approach-Attainment of the Equilibrium Solution

3. The Pure Theory of Public Expenditure: General Equilibrium

From Partial to General Equilibrium - Normative Solutions - The Basic General Equilibrium Welfare Analysis - Positive Solutions - Summary

4. Market Failure, Public Policy, and Public Expenditure

The Economic Framework of Public Expenditure - An Historical Overview of Economic Efficiency and Public PolicyStatic and Dynamic Efficiency - Public Goods and Market Failure - Joint Supply, Externalities, Exclusion, and Market Failure - Market Failure and Public Policies-Merit Goods - Which Goods Should Be Public? 
5. The Politics of Collective Choice

The Public Interest Approach - The Self-Interest Approach -Public Interest versus Private Interest

6. Program Budgeting

The Historical Dimensions - The Experience of the Department of Defense - Organizational Patterns - The Definition of Program - Measurement of Costs - Output Criteria The Benefits and Costs of Program Budgeting

7. Benefit-Cost Analysis

Historical Development - Operating Procedure - The General Concept - Criteria for Project Analysis - The Estimation of Benefits-Benefit-Cost Extensions-A General Appraisal

8. Fiscal Federalism

Political Organization-Fiscal Objectives-Fiscal Arrangements-The Grant-in-Aid

9. Determinants and Consequences of Public Expenditures

An Overview of Positive Aspects - Quantity and Quality of Public Services - The Determinants of Public Expenditures - Supply of Public Services - Incidence of Public Expenditure-Public Expenditure and Social States-Empirical Studies of the Effects of Expenditure - Organizational Theory

Name Index

Subject Index 